\title{
Penerapan Metode Jigsaw untuk Peningkatkan Hasil Belajar Ketrampilan Pengolahan Hasil Samping Seralia dan Umbi
}

\author{
Katmi Rahayu ${ }^{(1)}$ \\ ${ }^{1}$ SMP Negeri 2 Ngunut, Tulungagung

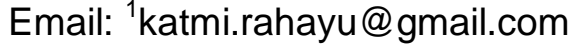

\begin{abstract}
ABSTRAK
Dalam rangka meningkatkan Hasil Belajar Ketrampilan Pengolahan yang memuat Pengolahan hasil samping seralia dan umbi menjadi produk non pangan pada Siswa Kelas VIII D SMP Negeri 2 Ngunut, Peneliti melakukan penelitian tindakan kelas dengan menerapkan Jigsaw pada pembelajaran Ketrampilan Pengolahan. Sasaran penelitian ini adalah siswa Kelas VIII D SMP Negeri 2 Ngunut yang berjumlah 33 siswa. Berdasarkan hasil observasi yang dilakukan di Kelas VIII D pada waktu pembelajaran Ketrampilan Pengolahan diperoleh hasil bahwa Hasil Belajar siswa kurang memuaskan, yaitu dari 33 siswa hanya 12 siswa yang nilainya dapat mencapai KKM atau $\geq 70$, sedangkan 21 siswa lainnya masih belum dapat mencapai KKM atau $\leq 69$. Simpulan dari penelitian ini adalah Jigsaw dapat meningkatkan Hasil Belajar siswa pada pembelajaran Ketrampilan Pengolahan yang memuat Pengolahan hasil samping seralia dan umbi menjadi produk non pangan.
\end{abstract}

Kata kunci: Hasil Belajar, Pengolahan hasil samping seralia dan umbi menjadi produk non pangan, Jigsaw.

\section{PENDAHULUAN}

Pendidikan prakarya diharapkan dilakukan dalam tatap muka pembelajaran di sekolah, tidak dibenarkan jika tugas praktek dikerjakan di rumah sebagai pekerjaan rumah yang melibatkan bantuan orang tua. Prakarya lebih menanamkan pendidikan keterampilan sehingga harus memperlihatkan proses agar pendidikan dapat dimaknai sebagai lifeskill, dimana dalam pelaksanaannya membutuhkan penerapan pendidikan karakter di sekolah.

Setiap karya yang dibuat peserta didik merupakan hasil belajar yang luar biasa dari potensi yang dapat ditampilkan oleh setiap anak. Mereka butuh diapresiasi, dihargai, dan diberi pujian dalam setiap kegiatan berkarya. Oleh karena itu, sebagai pendidik diharapkan dapat mempersiapkan ruang khusus untuk menampilkan karya mereka dalam sebuah event/pameran peserta didik. Setiap manusia perlu pujian karena pujian manusia dapat meningkatkan motivasi untuk menjadi lebih baik dan menjadi manusia yang unggul.

Mata Pelajaran Prakarya memberikan kesempatan kepada peserta didik untuk terlibat dalam berbagai pengalaman apresiasi dan berkreasi untuk menghasilkan suatu karya yang bermanfaat langsung bagi kehidupan peserta didik. Pembelajaran prakarya memfasilitasi pengalaman emosi, intelektual, fisik, persepsi, sosial, estetika, artistik dan kreativitas peserta didik dengan melakukan aktivitas apresiasi dan kreasi terhadap berbagai produk. Kegiatan ini dimulai dari mengamati, mengidentifikasi potensi di sekitar peserta didik, dan ekplorasi untuk diubah menjadi produk yang bermanfaat bagi kehidupan manusia.

Dalam proses pembelajaran di kelas sering timbul masalah yang pada umumnya dialami oleh siswa. Masalah yang dihadapi siswa bersifat unik berbeda satu sama lain. Misalnya masalah dan kesulitan ataupun rendahnya Hasil Belajar yang dialami siswa pada mata pelajaran Ketrampilan Pengolahan bisa terjadi karena berbagai faktor diantaranya, keterbatasan kemampuan, keadaan, minat dan motivasi diri siswa itu sendiri, situasi belajar di sekolah atau kelas dan kurangnya sarana dan 
prasarana, materi pelajaran yang kurang relevan dengan kebutuhan siswa dan pendekatan mengajar yang kurang bisa dipahami siswa bahkan kurangnya alat peraga dan alat bantu mengajar.

Apalagi mata pelajaran Ketrampilan Pengolahan menuntut kemampuan Guru untuk bisa membuat siswa mengerti dan memahami tentang materi yang diajarkan dengan tidak hanya membaca buku dan teori saja melainkan harus disertai alat peraga, contoh, praktek, latihan soal, seperti soal bercerita dan sebagainya, agar siswa memiliki pengetahuan, keterampilan dan bahkan sikap ilmiah yang berujung pada pemerolehan Hasil Belajar yang maksimal.

Berdasarkan hasil pengamatan dalam proses belajar mengajar dikelas, keadaan sekolah, dan melalui peninjauan bidang akademik dan non akademik, diperoleh hasil bahwa keadaan Sekolah Menengah Pertama Negeri 2 Ngunut khususnya siswa Kelas VIII D tahun ajaran 2015/2016 dalam pelajaran Ketrampilan Pengolahan belum menunjukkan Hasil Belajar sesuai dengan KKM yang ditetapkan terutama pada materi pelajaran Pengolahan hasil samping seralia dan umbi menjadi produk non pangan. Padahal, ditinjau dari keadaan fisik sekolah, yaitu ruang Kelas VIII D sudah baik dan sesuai sebagai tempat berlangsungnya proses belajar mengajar. Pengamatan pada proses pembelajaran oleh peneliti dapat disimpulkan bahwa pelaksanaan proses belajar mengajar lah yang belum membuat siswa aktif belajar, sehingga kemampuan siswa belum tergali dengan maksimal.

Pada ulangan harian Ketrampilan Pengolahan dengan materi Pengolahan hasil samping seralia dan umbi menjadi produk non pangan, di dapat rata-rata nilai sebesar 63,5 dari 33 siswa, padahal Kriteria Ketuntasan Minimalnya (KKM) telah ditentukan nilai sebesar 70. Dan hanya 13 siswa yang mendapat nilai di atas 70 . Hal ini berarti, hanya $36,4 \%$ dari siswa yang telah mencapai ketuntasan belajar, dan yang lainnya memiliki prestasi hasil belajar yang rendah

Dari hasil diskusi dengan teman sejawat ditemukan masalah-masalah dalam proses pembelajaran Ketrampilan Pengolahan yang menyebabkan menurunkan Hasil Belajar adalah materi kurang dapat dikuasi siswa secara optimal, penggunaan pendekatan pembelajaran dalam pembelajaran Ketrampilan Pengolahan pada siswa Kelas VIII D belum sesuai, siswa terlihat tidak antusias untuk belajar dan pembelajaran dengan pendekatan konvensional yaitu dengan menjelaskan materi dan siswa hanya melakukan perintah mengerjakan soal tanpa penanaman konsep pembelajaran yang kuat terlihat tidak efektif dalam proses peningkatan Hasil Belajar siswa.

Oleh karena itu, demi memperbaiki berbagai masalah yang ada, peneliti memerlukan suatu solusi untuk mengatasi hambatan-hambatan yang terjadi, peneliti menggunakan Jigsaw dalam pembelajaran Ketrampilan Pengolahan ini. Pembelajaran Jigsaw adalah salah satu model pembelajaran dimana siswa terlibat langsung dengan objek nyata sehingga dapat mempermudah pemahaman siswa terhadap materi pelajaran, sehingga siswa dapat menemukan sendiri konsep-konsep yang dipelajari dan berfikir kritis., sehingga Hasil Belajar siswa pun dapat meningkat.

Rumusan masalah dari penelitian ini adalah Bagaimana penerapan Jigsaw untuk meningkatkan Hasil Belajar Ketrampilan Pengolahan penguasaan Pengolahan hasil samping seralia dan umbi menjadi produk non pangan pada Siswa Kelas VIII D SMP Negeri 2 Ngunut?

Apakah penerapan Jigsaw dapat meningkatkan Hasil Belajar Ketrampilan Pengolahan materi Pengolahan hasil samping seralia dan umbi menjadi produk non pangan pada Siswa Kelas VIII D SMP Negeri 2 Ngunut?

Tujuan dari penelitian ini adalah mendeskripsikan penerapan Jigsaw pada Siswa Kelas VIII D SMP Negeri 2 Ngunut, dan meningkatkan Hasil Belajar siswa pada Ketrampilan Pengolahan yang memuat Pengolahan hasil samping seralia dan umbi menjadi produk non pangan melalui penerapan Jigsaw pada Siswa Kelas VIII D SMP Negeri 2 Ngunut.

Dalam pelaksanaan penelitian ini, peneliti berharap dapat memberikan manfaat bagi: 1) Peneliti (Guru) adalah (a) Sebagai saranan peningkatan mutu, ilmu 
pengetahuan, pendekatan dan seni mengajar (b) Sebagai jembatan bagi Guru agar lebih mudah berkomunikasi dengan siswa (c) Sebagai acuan dan bahan tinjauan dalam pembinaan dan penilaian terhadap Proses Belajar Mengajar (PBM) yang dilaksanakan Guru di sekolah (d) Hasil penelitian ini dapat dijadikan sebagai masukan untuk meningkatkan mutu dan kualitas pembelajaran di kelas. (2) Manfaat penelitian ini bagi siswa adalah: (a) Siswa dapat lebih mudah memahami materi pelajaran (b) Siswa lebih berani dalam bereksperimen dan menemukan hal baru (c) Dapat meningkatkan kemampuan siswa dalam menerima pembelajaran sehingga Hasil Belajar siswa pun menjadi lebih baik. (3) Manfaat penelitian ini bagi peneliti lain adalah hasil penelitian dapat dijadikan acuan dalam melakukan penelitian yang sejenis dan (4) Manfaat penelitian ini bagi kepala sekolah adalah hasil penelitian ini dapat dijadikan acuan dalam membuat kebijakan tentang peningkatan kualitas sekolah.

\section{METODE \\ Subjek, Tempat dan Waktu Penelitian}

Lokasi yang digunakan tempat penelitian adalah ruang Kelas VIII D Sekolah Menengah Pertama Negeri 2 Ngunut Tahun Pelajaran 2015/2016. Dalam penelitian ini subjek yang digunakan adalah seluruh siswa Kelas VIII D Sekolah Menengah Pertama Negeri 2 Ngunut sebanyak 33 siswa yang terdiri dari 17 siswa putra dan 16 siswa putri.

Penelitian dilaksanakan pada semester 2, adapun pada siklus pertama dilaksanakan pada hari Kamis, 24 Maret 2016 dan siklus kedua dilaksanakan pada hari Kamis, 31 Maret 2016.

\section{Desain Prosedur Perbaikan Pembelajaran}

Penelitian ini menggunakan pendekatan penelitian kualitatif dengan pendekatan penelitian tindakan kelas karena penelitian ini dilaksanakan berdasarkan adanya temuan masalah di kelas. Berdasarkan variable yang diteliti dan tujuan yang hendak dicapai, maka pendekatan penelitian yang digunakan adalah dengan sistem spiral. Stephen Kemmis dan Robin Mc Taggart tahun 1988 mengembangkan model Kurt Lewin dalam suatu sistem spiral dengan empat komponen utama, yakni perencanaan (planning), tindakan (acting), observasi (observing) dan refleksi (reflecting). Tahap pelaksanaan tindakan yaitu merupakan suatu hal yang dilakukan sebagai upaya perubahan yang dilakukan. Tahap observasi atau pengamatan yaitu mengamati secara sistematis hasil atau dampak tindakan terhadap proses belajarmengajar, dan tahap refleksi yaitu mengkaji dan mempertimbangkan hasil atau dampak tindakan yang dilakukan.

Peneliti dalam penelitian kualitatif berperan sebagai instrument penelitian, kehadiran peneliti mutlak diperlukan, dalam hal ini peneliti bertindak sebagai perencana, pelaksanaan pengajaran, pengumpul data, penganalisis, penafsir dan sebagai pelapor hasil penelitian. Peneliti berkolaborasi dengan teman sejawat sebagai observer. Penelitian ini bertempat di SMP Negeri 2 Ngunut Kabupaten Tulungagung. SMP Negeri ini termasuk lembaga pendidikan yang memiliki hasil output bagus dilingkup sekitarnya. Namun terlihat nilai pembelajaran Ketrampilan Pengolahan di Kelas VIII D belum maksimal, Guru lebih banyak berceramah, siswa hanya sebagai pendengar, kondisi seperti ini mengakibatkan siswa merasa bosan dan enggan belajar Ketrampilan Pengolahan dan susah dalam mengerjakan soal-soal Ketrampilan Pengolahan khususnya Pengolahan hasil samping seralia dan umbi menjadi produk non pangan. Selain itu, dilihat bahwa nilai Ketrampilan Pengolahan siswa masih belum menggembirakan karena masih terdapat siswa yang nilainya berada di bawah KKM. Dalam pelaksanaan Penelitian Perbaikan Pembelajaran ini yang akan menjadi subjek adalah Siswa Kelas VIII D SMP Negeri 2 Ngunut, yang berjumlah 33 siswa.

Berdasarkan hasil pengidentifikasian dan penetapan masalah, peneliti kemudian mengajukan suatu solusi yang berupa penerapan Jigsaw yang dapat dimanfaatkan Guru untuk digunakan sebagai pendekatan pengajaran dalam pembelajaran Ketrampilan Pengolahan Kelas VIII D SMP Negeri 2 Ngunut. Penelitian 
ini dilakukan dengan dua siklus, dimana masing-masing siklus dikenai perlakuan yang sejenis dengan bobot yang beda. Dibuat dua siklus dimaksudkan untuk memperbaiki system pengajaran yang dilaksanakan.. Pelaksanaan tindakan pada siklus 1 dan siklus 2 dibagi menjadi 4 tahapan yaitu (1) Persiapan awal, (2) pertemuan awal, (3) proses supervisi (observasi), dan (4) pertemuan balikan atau refkleksi.

Pengumpulan data dalam penelitian ini dapat dilakukan dengan menggunakan teknik observasi, angket, dokumentasi, tes, wawancara, dan catatan lapangan. Teknik analisis data yang digunakan dalam penelitian ini adalah teknik analisis data kualitatif yaitu menggambarkan kenyataan atau data sesuai dengan data yang diperoleh dengan tujuan untuk mengetahui peningkatan kualitas kinerja guru. Langkah-langkah analisis terdiri dari tiga alur kegiatan yang terjadi secara bersamaan yaitu: (1) reduksi data, (2) penyajian data, (3) penarikan kesimpulan.

Pada kegiatan reduksi data, peneliti mengumpulkan pelaksanaan pengembangan pembelajaran menggunakan Jigsaw dan Hasil Belajar siswa Data hasil reduksi yaitu pelaksanaan pengembangan pembelajaran menggunakan Jigsaw pada siklus 1 dan 2, data hasil observasi Guru pada siklus 1 dan siklus 2. Kegiatan penyajian data dilakukan dalam rangka mengorganisasikan hasil reduksi, dengan menyusun secara narasi sekumpulan informasi yang diperoleh dari hasil reduksi hingga memberi kemungkinan adanya penarikan kesimpulan dan pengambilan tindakan. Informasi yang dimaksud adalah apakah penerapan Jigsaw dapat meningkatkan Hasil Belajar siswa, Pengelolaan pembelajaran oleh Guru, respon siswa terhadap kegiatan pembelajaran, serta hasil yang diperoleh sebagai akibat dari pemberian tindakan. Sajian data selanjutnya ditafsirkan dan dievaluasi untuk merencanakan tindakan selanjutnya.

\section{Teknik Analisis Data}

Teknik analisis yang digunakan yaitu deskriptif persentase. Data hasil penelitian yang dianalisis meliputi rata-rata kelas, ketuntasan belajar individu dan ketuntasan belajar secara klasikal. Selanjutnya hasil analisis data diperoleh baik secara kualitatif (dengan kata-kata) dan kuantitatif (dengan grafik). Hasil ini diinterprestasikan dan disimpulkan untuk menjawab permasalahan yang ada

Kegiatan penarikan kesimpulan mencakup pencarian arti dan makna data serta memberi penjelasan. Makna dan arti yang diperoleh tersebut harus di uji kebenarannya serta kecocokannya melalui kegiatan verifikasi. Verifikasi tersebut merupakan validitas data yang disimpulkan. Hasil analisis data ini akan dijadikan dasar untuk menentukan keberhasilan pemberian tindakan. Selain itu analisis data ini akan digunakan dasar untuk melaksanakan tindakan selanjutnya, jika pemberian tindakan sebelumnya tidak berhasil. Berdasarkan analisis maka akan ditentukan mana yang perlu dilakukan perbaikan untuk pelaksanaan tindakan selanjutnya. Penarikan kesimpulan dilihat dari hasil ketuntasan belajar siswa baik secara individu maupun kelompok selama pembelajaran dengan menggunakan pengembangan Jigsaw.

Patokan penilaian yang digunakan adalah target indikator pencapaian persentase target ketercapaian pada indikator yang ditetapkan dalam penelitian ini berdasarkan pada hasil observasi yang dilakukan baik pra siklus, siklus 1 ataupun siklus 2, dikatakan indikator tercapai bila $85 \%$ dari siswa Kelas VIII D mendapat nilai Ketrampilan Pengolahan minimal di atas KKM atau 70

Evaluasi dilaksanakan setelah diperoleh hasil analisis yang akurat. Kegiatan evaluasi dilakukan untuk mengetahui keberhasilan penelitian dalam meningkatkan Hasil Belajar siswa melalui pembelajaran menggunakan Jigsaw pada pembelajaran Ketrampilan Pengolahan materi Pengolahan hasil samping seralia dan umbi menjadi produk non pangan, jika hasil penelitian belum sesuai dengan harapan, maka akan dicari penyebabnya. Untuk itu dalam penelitian juga diperlukan refleksi. Refleksi merupakan kegiatan memikirkan atau merenungkan kembali semua kegiatan yang telah dilakukan, kemudian mencari solusi perbaikan yang dapat dilakukan untuk meningkatkan keberhasilan tindakan yang dilakukan. 


\section{HASIL \\ Paparan Data Observasi Pra Siklus}

Sebelum melaksanakan proses penelitian, peneliti mengumpulkan data dan informasi tentang subjek penelitian. Data-data yang dikumpulkan antara lain daftar nama siswa Kelas VIII D, daftar nilai ulangan harian Ketrampilan Pengolahan materi Pengolahan hasil samping seralia dan umbi menjadi produk non pangan, hasil wawancara dengan informan yaitu siswa Kelas VIII D SMP Negeri 2 Ngunut. Dari pengumpulan data, nilai ulangan harian tentang Pengolahan hasil samping seralia dan umbi menjadi produk non pangan, rata-rata nilai yang didapat hanya sebesar 63,5 . Dari 33 siswa, hanya 12 siswa yang mendapat nilai di atas 70 . Ini berarti hanya $36,4 \%$ siswa yang telah mencapai ketuntasan belajar, karena Kriteria Ketuntasan Minimal (KKM) telah ditentukan sebesar 70. (Nama siswa dan nilai bisa dilihat di lampiran).

Daftar frekuensi nilai ulangan harian Ketrampilan Pengolahan Pengolahan hasil samping seralia dan umbi menjadi produk non pangan siswa Kelas VIII D SMP Negeri 2 Ngunut pada kondisi awal adalah terdapat 1 siswa atau 3,1\% yang mendapat nilai antara 0 - 40, ada 20 siswa atau 60,6\% yang mendapat nilai antara $41-69$, dan ada 12 siswa atau $36,4 \%$ yang mendapat nilai antara $70-100$. Dengan ketentuan nilai KKM 70, maka dapat disimpulkan jika pencapaian prestasi nilai $70-100$ yang hanya $36,4 \%$ merupakan prestasi yang rendah.

Selain itu, dari proses wawancara diperoleh kesimpulan bahwa siswa kurang berminat dalam melaksanakan kegiatan pembelajaran, serta dalam pembelajaran Guru lebih sering menggunakan ceramah sehingga siswa merasa jenuh dan bosan, akibatnya minat siswa untuk belajar Ketrampilan Pengolahan terutama pada Pengolahan hasil samping seralia dan umbi menjadi produk non pangan menjadi berkurang sehingga mempengaruhi hasil prestasinya

Berdasarkan hasil data yang dikumpulkan, dapat dikemukakan dua hal pokok yang perlu diatasi, yaitu menumbuhkan minat siswa untuk belajar Ketrampilan Pengolahan dan memahamkan Pengolahan hasil samping seralia dan umbi menjadi produk non pangan dengan cara mengaktifkan siswa dalam kegiatan belajar mengajar dan meningkatkan Hasil Belajar siswa dengan menerapkan Jigsaw pada siklus 1 nanti dengan harapan Hasil Belajar siswa dapat meningkat. Untuk itu perlu dilaksanakan perbaikan pembelajaran pada siklus 1 dan jika belum tuntas maka akan dilanjutkan pada siklus 2 .

\section{Tinjauan Siklus 1}

Pelaksanaan siklus I yang dilaksanakan pada hari Kamis tanggal 24 Maret 2016 di ruang Kelas VIII D SMP Negeri 2 Ngunut pada jam pertama dan kedua. Pertemuan direncanakan berlangsung $2 \times 40$ menit dilaksanakan pada jadwal terstruktur. Proses belajar mengajar mengacu pada rencana pembelajaran yang telah dipersiapkan.

Langkah peneliti antara lain adalah menyiapkan instrument penelitian, dan bahan ajar salah satunya Rencana Pelaksanaan Pembelajaran Siklus I materi pelajaran Ketrampilan Pengolahan Kelas VIII D semester 2, dengan Kompetensi Dasar 4.4 Membuat olahan dari hasil samping seralia dan umbi menjadi produk non pangan sesuai wilayah setempat. Mempersiapkan pula silabus, materi pelajaran, tugas kelompok atau lembar kegiatan, post test. Peneliti juga menyiapkan evaluasi, evaluasi digunakan peneliti untuk mengukur sejauh mana keberhasilan proses pembelajaran. Peneliti pun menyiapkan lembar observasi, untuk mengamati proses pembelajaran dan lembar angket untuk mengetahui hasil pendekatan pembelajaran.

Kegiatan diawali dengan menjelaskan tentang pendekatan yang akan digunakan yaitu Jigsaw dan komponen-komponennya kepada siswa. Guru membuka pelajaran dengan mengucapkan salam. Guru memberikan apersepsi kalimat Pengolahan hasil samping seralia dan umbi menjadi produk non pangan. 
Vol. 1 No. 1, Oktober 2017

Setelah itu, siswa dibagi ke dalam 6 (lima) kelompok sesuai absensi, setelah itu Guru atau Peneliti memberikan penjelasan tentang tujuan pembelajaran dan garis besar Ketrampilan tentang Pengolahan hasil samping seralia dan umbi menjadi produk non pangan.

Setelah siswa bergabung ke dalam kelompoknya masing-masing. Guru atau Peneliti membagi tugas kepada setiap kelompok. Siswa diberikan serealia dan umbi serta alat dan bahan yang diperlukan untuk diobservasi, Kemudian mengidentifikasi jenis hasil samping dari serealia dan umbi di daerah masing-masing. Mencatat jenis dan manfaatnya serta latar belakang budaya sosial pemanfaatan hasil sampingnya dalam bentuk laporan.(lihat lampiran).

Dalam pelaksanaan kegiatan percobaan, Guru memberi bimbingan. Secara berkelompok, siswa berdiskusi untuk merumuskan simpulan dari hasil curah pendapat tentang Pengolahan hasil samping seralia dan umbi menjadi produk non pangan. Pelaksanaan percobaan ini sebagai penerapan awal Metode Jigsaw digunakan untuk menguji jawaban sementara)

Setelah kegiatan kelompok selesai, dilanjutkan dengan diskusi kelas yang dipandu oleh Guru untuk membahas hal-hal yang tidak atau belum terselesaikan dalam kegiatan kelompok. Guru secara bergilir mendekati masing-masing kelompok untuk memberikan penguat serta penjelasan sesuatu hal yang belum dipahami oleh siswa (Kegiatan diskusi adalah kegiatan metode Jigsaw menarik kesimpulan)

Guru atau peneliti membacakan hasil diskusi di depan kelas. Guru berperan sebagai moderator untuk membantu siswa menanggapi hasil presentasi hasil diskusi, atas perintah Guru, kemudian salah satu siswa perwakilan dari masing-masing kelompok melaporkan hasil diskusinya dimuka, siswa yang lain memperhatikan. Guru memberikan ulasan terhadap materi yang belum tersentuh oleh kerja kelompok siswa, serta memberikan ulasan terhadap materi yang belum tersentuh oleh kerja kelompok siswa.

Secara bersama-sama, Guru mengambil simpulan dan mendiskusikannya bersama siswa. Guru memberikan post tes atau quis untuk mengukur keberhasilan yang dicapai siswa. (lembar soal dapat dilihat di lampiran). Sehingga bisa dilihat peningkatan prestasi hasil belajarnya.

Terdapat 12 siswa atau 36,4\% yang mendapat nilai antara $41-69$, dan 21 siswa atau $63,6 \%$ yang mendapat nilai antara 70 - 100. Dengan ketentuan nilai KKM 70 , dapat disimpulkan jika pencapaian prestasi nilai $70-100$, maka prestasi hasil belajar siswa telah meningkat dari 36,4\% menjadi 63,6\%. Namun karena belum mencapai target indicator pencapaian siklus I sebesar $85 \%$ atau lebih, maka akan dilanjutkan ke Siklus II.

Selain itu, dari proses wawancara diperoleh kesimpulan bahwa beberapa siswa menjadi bersemangat dalam belajar Ketrampilan Pengolahan, karena pelaksanaan kegiatan belajar Ketrampilan Pengolahan dengan Jigsaw ini dilaksanakan dengan langsung secara mandiri oleh siswa, dan melaksanakan kegiatan bersama kelompok sehingga lebih ringan. Meskipun masih terdapat kendala-kendala seperti yang telah diuraikan dalam laporan observasi.

\section{Tinjauan Siklus 2}

Berdasarkan hasil refleksi pada siklus I, disepakati bahwa siklus kedua perlu dilaksanakan. Pelaksanaan siklus II yang dilaksanakan pada hari Kamis, tanggal 31 Maret 2016 di SMP Negeri 2 Ngunut pada jam pertama dan kedua. Pertemuan direncanakan berlangsung $2 \times 40$ menit dilaksanakan pada jadwal terstruktur. Proses belajar mengajar mengacu pada rencana pembelajaran yang telah dipersiapkan. Pengamatan (observasi) dilaksanakan bersamaan dengan pelaksaaan belajar mengajar.

Pada siklus 2 ini, Guru lebih memperhatikan dan mendekati siswa dan kelompok yang memerlukan bimbingan, Guru memberi bimbingan bagi siswa dan kelompok yang memerlukan, Guru memandu siswa dalam melaksanakan percobaan, 
Karena pada siklus I diketahui masih banyak siswa yang malu untuk maju presentasi dan mengajukan pertanyaan, maka pada siklus II ini Guru memberikan reward kepada siswa yang mau maju presentasi dan aktif dalam diskusi baik bertanya maupun menjawab pertanyaan.

Langkah peneliti antara lain adalah menyiapkan instrument penelitian, dan bahan ajar salah satunya Rencana Pelaksanaan Pembelajaran Siklus II Mata pelajaran Ketrampilan Pengolahan Kelas VIII D semester 2, dengan Kompetensi Dasar 4.4 Membuat olahan dari hasil samping seralia dan umbi menjadi produk non pangan sesuai wilayah setempat. Mempersiapkan pula silabus, materi pelajaran, tugas kelompok atau lembar kegiatan, post test. Peneliti juga menyiapkan evaluasi soal, evaluasi digunakan peneliti untuk mengukur sejauh mana keberhasilan proses pembelajaran. Peneliti pun menyiapkan lembar observasi, untuk mengamati proses pembelajaran dan lembar angket untuk mengetahui hasil pendekatan pembelajaran

Langkah-langkah yang dilakukan Guru dalam pelaksanaan siklus II ini antara lain, kegiatan diawali dengan Guru membuka pelajaran dengan mengucapkan salam; Guru mengulang materi yang lampau yang oleh Guru untuk berkaitan dengan materi yang akan disampaikan sekarang; Memberikan apersepsi dengan memberikan soal mencongak tentang Pengolahan hasil samping seralia dan umbi menjadi produk non pangan.

Menjelaskan kembali tentang metode yang akan digunakan yaitu Metode Jigsaw dan komponen-komponennya kepada siswa. Siswa menuju kelompoknya masing-masing, setelah itu Guru atau peneliti memberikan penjelasan lagi tentang tujuan pembelajaran dan garis besar Ketrampilan tentang Pengolahan hasil samping seralia dan umbi menjadi produk non pangan,

Setelah siswa bergabung ke dalam kelompknya masing-masing. Guru membagikan lembar kegiatan yang berisi petunjuk pelaksanaan percobaan untuk penemuan, kemudian menugaskan siswa untuk melaksanakannya, yaitu mengobservasi teknik pengolahan hasil samping serealia dan umbi. Mewawancarai pembuat tentang proses pembuatannya, alat dan bahan yang digunakan, dan bentuk penyajian. Dicatat dalam bentuk laporan. (lihat lampiran). Dalam pelaksanaan kegiatan percobaan, Guru memberi bimbingan. Siswa melaksanakan kegiatan percobaan sesuai lembar kegiatan, (lihat lampiran).

Pelaksanaan percobaan ini sebagai penerapan kedua dan digunakan untuk menguji jawaban kelemahan siklus I).

Setelah kegiatan kelompok selesai, dilanjutkan dengan diskusi kelas yang dipandu membahas hal-hal yang tidak atau belum terselesaikan dalam kegiatan kelompok. Selama siswa berdiskusi, Guru secara bergilir mendekati masing-masing kelompok untuk memberikan penguat serta penjelasan sesuatu hal yang belum dipahami oleh siswa. (Kegiatan diskusi adalah kegiatan metode Jigsaw menarik kesimpulan)

Guru atau peneliti membacakan hasil diskusi di depan kelas. Guru berperan sebagai moderator untuk membantu siswa menanggapi hasil presentasi hasil diskusi, atas perintah Guru, kemudian salah satu siswa perwakilan dari masing-masing kelompok melaporkan hasil diskusinya dimuka, siswa yang lain memperhatikan. Guru memberikan ulasan terhadap materi yang belum tersentuh oleh kerja kelompok siswa, serta memberikan ulasan terhadap materi yang belum tersentuh oleh kerja kelompok siswa. Sebagai perbaikan siklus I, Guru memberikan reward kepada siswa yang aktif dalam diskusi dan presentasi. Dengan iming-iming reward yang ditawarkan Guru, banyak dari siswa menjadi aktif dalam diskusi dan bertanya ataupun menjawab pertanyaan, bahkan di antara kelompok mereka saling berebut untuk presentasi di depan kelas.

Secara bersama-sama, Guru mengambil simpulan dan mendiskusikannya bersama siswa. Guru memberikan post tes atau quis untuk mengukur keberhasilan yang dicapai siswa. 
Terdapat 3 siswa atau 9,1\% yang mendapat nilai antara $41-69$, dan 30 siswa atau $90,9 \%$ yang mendapat nilai antara 70 - 100. Dengan ketentuan nilai KKM 70, dapat disimpulkan jika pencapaian prestasi nilai 70 - 100, maka prestasi hasil belajar siswa telah meningkat dari $63,6 \%$ menjadi $90,9 \%$. Dengan $90,9 \%$ maka telah tercapai indicator pencapaian siklus II sebesar yang $85 \%$ atau lebih, maka tidak perlu dilanjutkan ke Siklus III.

Selain itu, dari proses wawancara diperoleh kesimpulan bahwa beberapa siswa menjadi bersemangat dalam belajar Ketrampilan Pengolahan, karena pelaksanaan kegiatan belajar Ketrampilan Pengolahan dengan Jigsaw ini dilaksanakan dengan melibatkan masing-masing anggota kelompok, dan didiskusikan bersama kelompok sehingga mereka lebih rileks dan ringan dalam mengerjakan laporan kegiatan. Meskipun masih terdapat kendala-kendala seperti yang telah diuraikan dalam laporan observasi

\section{PEMBAHASAN}

Berdasarkan hasil pelaksanaan pada siklus I, II dapat dinyatakan bahwa terjadi peningkatan kualitas pembelajaran yang tampak dan perolehan hasil evaluasi dan keaktifan siswa.

Dari tabel 4.2 dan gambar 4.2 siklus I hasil observasi menunjukkan, prosentase keberhasilan kelengkapan menyiapkan alat dan bahan percobaan $45 \%$, prosentase keruntutan langkah-langkah yang ditempuh dalam pelaksanaan percobaan $37 \%$, prosentase keaktifan siswa dalam melaksanakan kegiatan percobaan $58 \%$, prosentase keaktifan siswa dalam mengutarakan pendapat saat berdiskusi $45 \%$ dan prosentase hasil penarikan kesimpulan akhir sesuai percobaan $46 \%$.

Berdasarkan tabel 4.5 dan gambar 4.4 siklus II hasil observasi menunjukkan, prosentase keberhasilan metode kelengkapan menyiapkan alat dan bahan percobaan siswa yang disiapkan $75 \%$, prosentase keruntutan langkah-langkah yang ditempuh dalam pelaksanaan percobaan $85 \%$, prosentase keaktifan siswa dalam melaksanakan kegiatan percobaan $90 \%$, prosentase keaktifan siswa dalam mengutarakan pendapat saat berdiskusi $88 \%$ dan prosentase hasil penarikan kesimpulan akhir sesuai percobaan $84,5 \%$.

Dari daftar nilai (lihat lampiran) dapat kita lihat adanya prosentase kenaikan nilai Ketrampilan mulai dari kondisi awal pra tindakan, diketahui baru 12 siswa atau $36,4 \%$ yang mengalami ketuntasan belajar dan mendapatkan nilai sesuai dengan KKM. Hasil evaluasi siklus I menunjukkan baru 21 siswa atau 63,6\% yang mengalami ketuntasan belajar dan mendapat nilai sama dengan atau di atas KKM yaitu 70. Hal itu menunjukkan bahwa pelaksanaan siklus I belum mencapai keberhasilan, karena indicator pencapaian adalah sebesar $85 \%$ atau lebih. Siklus II menunjukkan ada 30 siswa atau $90,9 \%$ dari 33 siswa yang mengalami ketuntasan belajar. Sehingga peneliti menyimpulkan bahwa pada siklus II ini peneliti telah mencapai keberhasilan dari penelitian tindakan kelas yang telah dilakukan.

Ketika peneliti melaksanakan siklus I, peneliti mengalami berbagai kendala antara lain masih ada siswa masih belum dapat memahami serealia dan umbi serta alat dan bahan yang diperlukan, sehingga suasana kelas tampak sedikit ramai dan gaduh, diwarnai dengan siswa yang banyak bertanya kepada Guru. Masih ada kelompok yang bingung dalam mengikuti langkah-langkah yang tertera dalam lembar kegiatan. Masih ada beberapa siswa yang belum aktif dalam pelaksanaan percobaan. Ketika pelaksanaan diskusi, ada beberapa siswa yang tidak aktif menyampaikan pendapatnya. Dalam menyimpulkan hasil percobaan, terdapat 3 (tiga) kelompok yang malu untuk presentasi, dan hanya terdapat 3 (tiga) siswa yang mengajukan pertanyaan.

Peneliti kemudian melaksanakan siklus II sebagai perbaikan siklus I, sebelum pelaksanaan siklus II ini peneliti mengganti rencana pembelajaran Metode Jigsaw baru yaitu dengan mengobservasi teknik pengolahan hasil samping serealia dan umbi. Mewawancarai pembuat tentang proses pembuatannya, alat dan bahan yang 
digunakan, dan bentuk penyajian. Dicatat dalam bentuk laporan. Dalam pelaksanaan percobaan, peneliti senantiasa memberi bimbingan untuk siswanya dalam melaksanakan langkah-langkah sesuai lembar kegiatan. Peneliti pun memberi bimbingan siswa saat berdiskusi untuk menarik kesimpulan. Dengan adanya motivasi guru berupa reward, siswa telah terlihat aktif dalam kegiatan pembelajaran dalam melaksanakan percobaan, presentasi di depan kelas dan berdiskusi menarik kesimpulan. Meskipun ada kendala yaitu siswa masih kesulitan dalam menemukan data, namun dengan hasil prestasi hasil belajar yang dicapai dapat disimpulkan bahwa penelitian tindakan kelas dari siklus II ini telah berhasil.

\section{KESIMPULAN}

Penerapan Jigsaw dapat meningkatkan Hasil Belajar Ketrampilan Pengolahan siswa Kelas VIII D SMP Negeri 2 Ngunut. Hal ini dilihat dari prosentase kenaikan nilai Ketrampilan Pengolahan siswa Kelas VIII D dari pra siklus, siklus I sampai Siklus II. Pada pra siklus, siswa yang mendapat nilai minimal 70 ada 12 siswa atau $36,4 \%$, pada siklus I siswa yang mendapat nilai minimal 70 ada 21 siswa atau $63,6 \%$, pada siklus II siswa yang mendapat nilai minimal 70 ada 30 siswa atau $90,9 \%$ dari 33 siswa. Dari pra siklus kemudian dilaksanakan siklus I prestasi siswa mengalami prosentase kenaikan $27,3 \%$. Dan dari siklus I kemudian dilaksanakan siklus II prestasi siswa mengalami prosentase kenaikan $27,3 \%$..

Penerapan pembelajaran dan prosedur dalam penelitian ini didasarkan pada pembelajaran dengan menerapkan Jigsaw dalam pelaksanaan proses pembelajaran Ketrampilan Pengolahan. Model yang dipakai dalam penelitian tindakan kelas ini adalah model siklus, adapun prosedur penelitiannya terdiri dari 2 siklus. Siklus I dilaksanakan pada hari Kamis tanggal 24 Maret 2016, Kompetensi Dasar 4.4 Membuat olahan dari hasil samping seralia dan umbi menjadi produk non pangan sesuai wilayah setempat. Siklus II dilaksanakan hari Kamis tanggal 31 Maret 2016.

Dalam setiap pelaksanaan siklus terdiri dari 4 (empat) tahapan, yaitu perencanaan tindakan, pelaksanaan, observasi, dan refleksi, kegiatan ini dilaksanakan berdaur ulang. Sebelum melaksanakan tindakan dalam tahap siklus, perlu perencanaan. Perencanaan ini memperhatikan setiap perubahan yang dicapai pada siklus sebelumnya terutama pada setiap tindakan yang dapat meningkatkan Hasil Belajar siswa. Hal ini didasarkan pada analisis perkembangan dari pra siklus, siklus I sampai siklus II.

Berdasarkan kriteria temuan dan pembahasan hasil penelitian seperti yang diuraikan pada bab IV, maka penelitian ini dapat digunakan peneliti untuk membantu guru dalam menghadapi permasalahan yang sejenis. Disamping itu, perlu penelitian lanjut tentang upaya guru untuk mempertahankan atau menjaga dan meningkatkan Hasil Belajar siswa. Pembelajaran dengan menggunakan Jigsaw ini pada hakikatnya dapat digunakan dan dikembangkan oleh guru yang menghadapi permasalahan yang sejenis, terutama untuk mengatasi masalah peningkatan Hasil Belajar siswa.

Berdasarkan hasil observasi dan pelaksanaan siklus I dan II juga dapat kita amati adanya perubahan kenaikan prosentase dalam menyiapkan alat dan bahan, keruntutan langkah-langkah siswa dalam melaksanakan percobaan, keaktifan siswa dalam melaksanakan kegiatan percobaan, keaktifan siswa ketika berdiskusi dan hasil akhir atau simpulan yang diperoleh dari hasil kegiatan diskusi

\section{SARAN}

Berikut saran yang dapat diajukan berkaitan dengan penelitian ini, untuk melaksanakan pengembangan pembelajaran menggunakan Jigsaw memerlukan persiapan yang cukup matang, sehingga guru harus mampu menentukan atau memilih topik yang benar-benar bisa dikembangkan dengan Pengembangan Pembelajaran menggunakan Jigsaw dalam proses belajar mengajar sehingga memperoleh hasil yang optimal. Dalam rangka meningkatkan kualitas kinerja Guru, guru hendaknya lebih sering melatih Guru dengan berbagai pendekatan pengajaran, walau dalam taraf yang 
sederhana, dimana Guru nantinya dapat menemukan pengetahuan baru, memperoleh konsep dan keterampilan, sehingga Guru berhasil atau mampu memecahkan masalahmasalah yang dihadapi. Perlu adanya penelitian yang lebih lanjut, karena hasil penelitian ini hanya dilakukan di SMP Negeri 2 Ngunut semester 2 tahun pelajaran 2015/2016, dan untuk peneltian yang serupa hendaknya dilakukan perbaikanperbaikan agar diperoleh hasil yang lebih baik.

\section{DAFTAR RUJUKAN}

Anonim. 2011. Model Pembelajaran Kooperatif Tipe Jigsaw. [Online]. Tersedia: http://repository.upi.edu/operator/upload/s_d0251_060231_chapter2.pdf [6 Juni 2016]

Depdikbud. 2006. Kurikulum Tingkat Satuan Pendidikan (KTSP-SMP). Departemen Pendidikan Nasional.

Dimyati \& Mudjiono, 2006. Belajar dan Pembelajaran. Jakarta: Rineka Cipta.

Djamarah, Syaiful Bahri. 2002. "Psikologi Belajar". Jakarta : PT. Rineka Cipta

Fadhly. 2010. Model Pembelajaran Kooperatif Teknik Jigsaw. [Online]. Tersedia: http://sumsel.kemenag.go.id/file/dokumen/modeljigsaw.pdf [18 Mei 2016]

Fudyartanto, Ki RBS. 2002. Psikologi Pendidikan dengan Pendekatan Baru. Yogyakarta: Global Pustaka IImu.

Hayinah. 1982. Masalah Belajar, Malang: IKIP Negri Malang.

Kasim, Melany. 2016. Model Pembelajaran Ketrampilan, (Online), Http: // Wodrpres. Com.

Kamus Besar Bahasa Indonesia 2002. Departemen Pendidikan Nasional Edisi ke-3. Balai Pustaka, Jakarta. Gramedia.

Muhibbin Syah. 2003. Psikologi Belajar. Jakarta: PT. Raja Grafindo Persada

Sanjaya, Aden. 2011. Prestasi Belajar. Tersedia di http: //adesanjaya.blogspot.com.

Slavin, R. E. 1994. Educational Psychology Theory Into Practices. 4th ed. Boston: Ally and Bacon Publishers.

Sudjana Nana. 2009. Penilaian Hasil Proses Belajar Mengajar. Bandung: Remaja Rosdakarya.

Syah, M., 1996. Psikologi Pendidikan Suatu Pendekatan Baru. Bandung: PT Remaja Rosdakarya. 